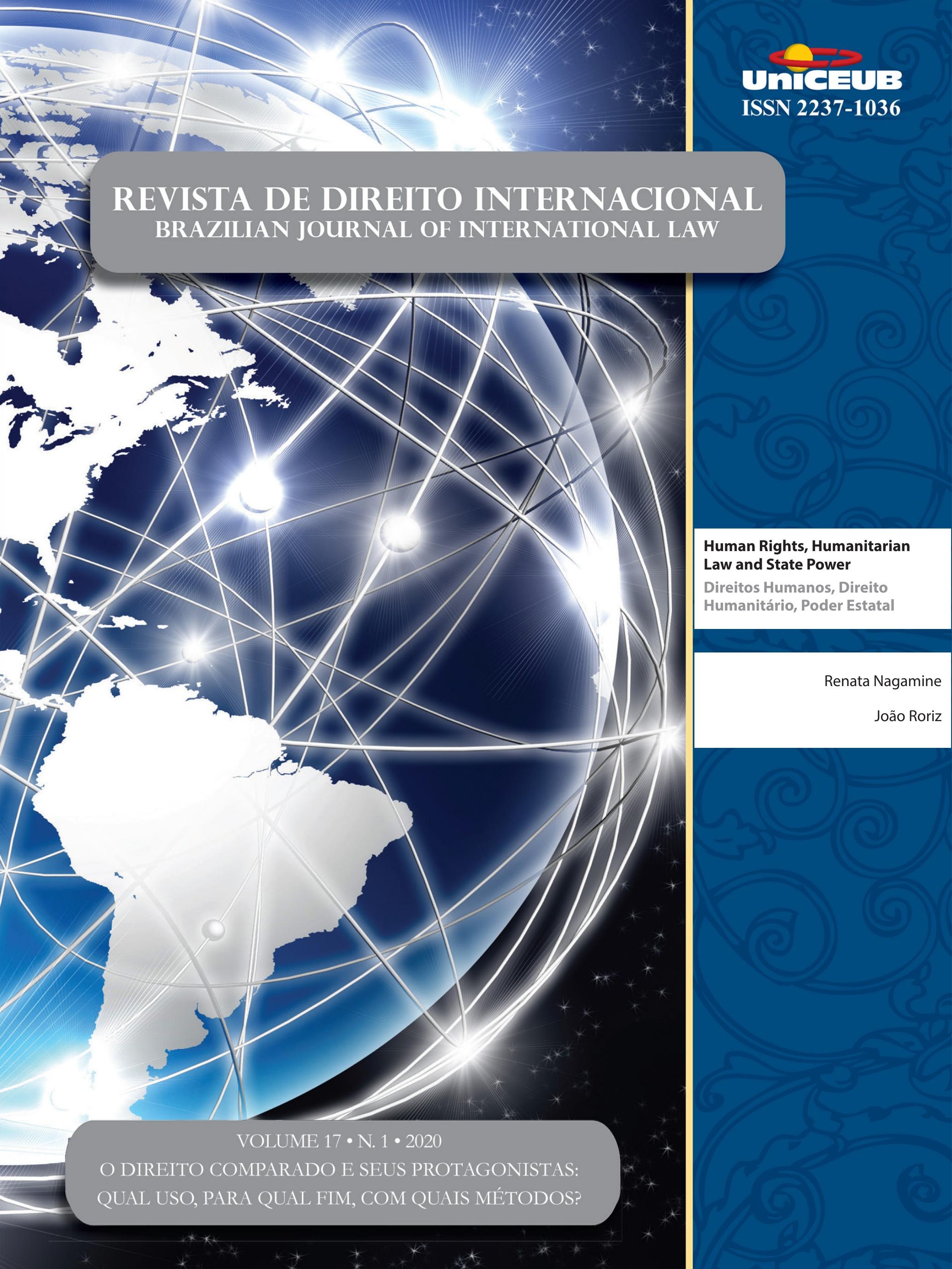


Parte I - O Direito comparado e seus Protagonistas: QuAL uso, PARA QUAL FIM, COM QUAIS MÉTODOS? .....................................................................1

EDITORIAL ............................................................................................................... 3

"Tudo o que precisamos fazer é ter certeza de que continuaremos conversando".............................. 3

Gustavo Cerqueira e Patrícia Perrone Campos Mello

Direito comparado E METOdologia $\quad$................................................... 6

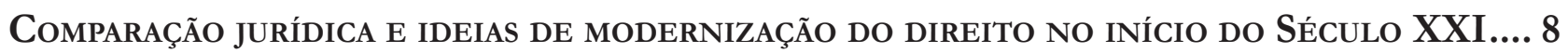
Gustavo Cerqueira

O DIREITO COMPARADO: ESFORÇO DE RESGATE HISTORIOGRÁFICO E DE PROBLEMAS METODOLÓGI$\cos$

Arnaldo Sampaio de Moraes Godoy e Gustavo Fereira Ribeiro

Direito Comparado e Política: Reflexões Necessárias .42

Raphael Carvalho de Vasconcelos e Deo Campos Dutra

Direito comparado no Brasil

L'originalité du Droit Brésilien et le Droit Comparé .57

Arnoldo Wald

LEI DA BOA RAZÃo E COMPARATISMO JURÍDICO NA DOUTRINA CIVILISTA BRASILEIRA DE 1850 A 1880

Alan Wruck Garcia Rangel

O STF EM REDE? QUANTO, COMO, COM QUE ENGAJAMENTO ARGUMENTATIVO O STF USA PRECEDENTES ESTRANGEIROS EM SUAS DECISÕES?

Patrícia Perrone Campos Mello e Felipe Meneses Graça 
Suprema Imprecisão: a metodologia em Direito Constitucional Comparado E as deficiênCias Em Seu uso pelo Supremo Tribunal Federal

Alonso Freire e Hugo Sauaia

Direitos comparados

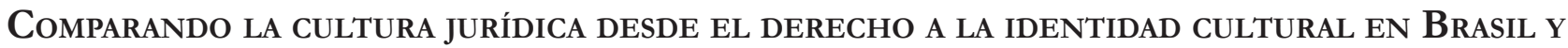

Chile 145 Juan Jorge Faundes e Fabien Le Bonniec

O Divino e o Racional no Direito: notas para um diálogo entre sistemas jurídicos 181 Salem Hikmat Nasser e José Garcez Ghirardi

Regulação do discurso de Ódio: análise comparada em países do Sul Global 196 Jane Reis Gonçalves Pereira, Renan Medeiros de Oliveira e Carolina Saud Coutinho

Parte II - Outros temas

LA OTRA CARA DE LA MONEDA: PROTECCIÓN CONSTITUCIONAL DE LA EMPRESA, EL EMPRENDIMIENTO Y LA LIBRE COMPETENCIA EN CHILE y COLOMBiA

Juan Pablo Díaz Fuenzalida e Juan Sebastián Villamil Rodríguez

The European Court of Human Rights Decision on there 'Burqa Ban'and the CritiCal analysis of the Pragmatic experimental logic 258 Flavianne Fernanda Bitencourt Nóbrega e George Browne Rego

Direitos humanos das deslocadas ambientais e os impactos da Usina de Belo Monte: da EXPLORAÇÃO AMAZÔNICA À SUBJUGAÇÃO FEMININA

Thais Silveira Pertille e Letícia Albuquerque

Solução de Controvérsias em Acordos de Investimento: as experiênCias do CPTPP, CETA E DOS ACFIs

Fábio Morosini, Vivian Daniele Rocha Gabriel e Anastacia Costa

50 anos dos “direitos da Criança” na Convenção Americana de Direitos Humanos: a HISTÓRIA DO ARTIGO 19 311

Sven Peterke e Paloma Leite Diniz Farias 
EMPRESAS E DIREITOS HUMANOS: COMPARTILHANDO VALOR E RESPONSABILIDADES .325 Melina Girardi Fachin

CONTEMPORARY RESPONSES TO BUSINESSES' NEGATIVE HUMAN RIGHTS IMPACT 341 Andres Felipe Lopez

Human Right to LABOR PROTECTION IN UKRAINE: CURRENT SITUATION AND THE PROSPECTS OF IMPLEMENTATION OF INTERNATIONAL RULES 363 Nina Daraganova

International Regulation and Global Governance: The EU influential Method IN TIMES OF NORMATIVITY CHANGE 373 Gabriela Hühne Porto, Paula Wojcikiewicz Almeida e Juliana Maia F. A. Netto

Tecnologias digitais e o comércio de bens E SERviços na OMC/Digital. 391 Umberto Celli Junior

Los fuertes hacen lo QUe PUeden: exponiendo los límites de la Corte Penal InternaCIONAL .406

Cristián D. González-Ruiz e Víctor M. Mijares

Human Rights, Humanitarian Law and State Power 418 Renata Nagamine e João Roriz

Regional integration in the South Pacific: Challenges for Public governance .433 Joanna Siekiera

Parte III - Resenhas 443

RESENHA DA OBRA

“Democracia e policentrismo do poder", de Murilo Gaspardo 445 Angela Limongi Alvarenga Alves 


\title{
Human Rights, Humanitarian Law and State Power*
}

\section{Direitos Humanos, Direito Humanitário, Poder Estatal}

\author{
Renata Nagamine ${ }^{* *}$ \\ João Roriz***
}

\begin{abstract}
This article deals with the relationship between humanitarian law and human rights. Our argument is that the emergence of human rights as a particular language of political transformation in the 1970s had a crucial impact on traditional readings of international humanitarian law. On one hand, the breakthrough of rights language created favorable conditions for humanitarian norms to reclaim its relevance in law and politics nowadays. On the other, it obliged humanitarian norms to share space in the legal imaginary with the novel language of social emancipation of rights. We examine how the construction of legal arguments within a rights vocabulary may blur legal definitions and create space for abuses. Finally, we analyse specific situations where human rights law facilitates the state to use its powers in spite of humanitarian norms.
\end{abstract}

Keywords: Humanitarian Law. Human Rights Law. International Criminal Law.

\section{Resumo}

Este artigo trata da relação entre direito humanitário e direitos humanos. Nosso argumento é que o surgimento dos direitos humanos como uma linguagem específica de transformação política na década de 1970 teve um impacto crucial nas leituras tradicionais do direito internacional humanitário. De um lado, o avanço da linguagem dos direitos humanos criou condições favoráveis para que as normas humanitárias recuperassem sua relevância no direito e na política atualmente. Por outro, obrigou as normas humanitárias a dividirem espaço no imaginário jurídico com a nova linguagem da emancipação social dos direitos. Analisamos como a construção de argumentos legais dentro de um vocabulário de direitos pode obscurecer as definições legais e criar espaço para abusos. Finalmente, analisamos situações específicas em que a lei de direitos humanos facilita o estado a usar seus poderes, apesar das normas humanitárias.

Palavras-chave: Direito humanitário. Direito dos Direitos Humanos. Direito Penal Internacional. 


\section{Introduction}

The most violent conflict between Latin American countries in the $19^{\text {th }}$ century, the Paraguayan War or Triple Alliance War (1864-1870), defined the fate of the Southern Cone. In Brazil, it fostered the decline of the monarchy and the rise of the military into politics. In Argentina and Uruguay, the war consolidated the nation-state and its local elites. The consequences were dreadful for all, but undoubtedly Paraguay suffered the most: not only its economy and institutions were destroyed, but its population shrank considerably. ${ }^{1}$ There is little evidence on the role of law in such conflict, specifically if the belligerents followed any norms conducting the hostilities. Surely legal arguments were around in a time when lawyers were amongst the decision-makers: the Brazilian historian Francisco Doratioto describes how norms and punishments were used to guarantee discipline and order amongst the troops, and how crimes such as desertions were treated during the hostilities. In his narrative, reports of torture, ill treatment and attacks on civilians are along with some principles such as reciprocity regarding the treatment of prisoners of war. ${ }^{2}$ Nonetheless, a detailed appraisal of international law and the Paraguayan War is yet to be written.

In 1867 - thus, during the Paraguayan War - Antonio de Vasconcellos Menezes de Drummond (1819-1876) published one of the first international law textbooks in Brazil intended to educate its burgeoning state bureaucracy and political elite. He dedicated few words to the Paraguayan War, usually with a nationalist tone against the 'Paraguayan dictator'. Regarding the new methods of warfare, he welcomed the gunpowder and long-distance artillery that "gave war a less barbaric physiognomy". ${ }^{3}$ With

\footnotetext{
The traditional historiography count that its population shrink by nearly 70 percent, (e.g., WHIGHAM, Thomas. The paraguayan war: causes and early conduct. 2. ed. Calgary: University of Calgary Press, 2018.), although more detailed studies show that such numbers are disputed (e.g., DORATIOTO, Francisco. Maldita guerra: nova história da Guerra do Paraguai. 2. ed. São Paulo: Companhia das Letras, 2002.)

2 According to Doratioto, in 1869 there were 2.458 Paraguayans prisoners of war in Brazil. Some of them were children who received a formal education. A similar treatment was given to Brazilian prisoners in Paraguay. (DORATIOTO, Francisco. Maldita guerra: nova história da Guerra do Paraguai. 2. ed. São Paulo: Companhia das Letras, 2002.).

3 "A invenção da polvora, a introducção das novas armas, que permittem levar longe a morte, as sábias complicações da arte militar modema, que são os meios de paralysar as forças do inimigo, inutilisar as suas munições e pô-los fóra de combate, deram à guerra uma
}

no further clarifications or examples, he states that Brazil followed the humanitarian principles during the hostilities. His account of the war of his time adds little to its historiography, but his thoughts on the general relation of law and war shed some light on his legal thinking. For him, war is a natural phenomenon, an "inevitable evil", but one which has its own rules. He understands the laws of war both as the "restrictions established between civilised nations" during war and the "necessary means to its end". Law regulates war by placing 'restrictions', and also by allowing 'means' - a common construction as we will see. Even though such norms come from agreements from 'civilised nations', the "true regulator of war is Christian morality and modern civilisation - so that no acts of barbarity are perpetrated". ${ }^{4}$

There are many concurrent historiographies dedicated to the rules applied in times of war. An orthodox perspective traces thin lines connecting current humanitarian law to ancient customs and practices. To a commentator, rules regarding the conduct of warfare "have existed since most ancient times in all civilizations", such as ancient China, Black Africa, Pre-Colombian America and even rules mentioned in the Old Testament. ${ }^{5}$ Others point to the late $19^{\text {th }}$ and early $20^{\text {th }}$ centuries as the time when rules, principles and practices regarding warfare received its current design. Drummond's account of law and war would be an example of this legal thinking. In this article, we are more interested in this later understanding. More specifically, we analyse the relation of the legal reasoning on warfare that arose in the $20^{\text {th }}$ century and its relation to another influential legal idea, that of human rights. To an influential jurist, "the phrase 'international humanitarian law' has increasingly supplanted terms such as the 'law of war' and the 'law

physionomia menos barbara" (DRUMMOND, Antonio de Vasconcellos Menezes de. Prelecções de direito internacional: com referencia e applicação de seus princípios a's leis particulares do brasil até 1867 . Recife: Typographia do Correio do Recife, 1867.).

4 "o verdadeiro regulador da guerra é a moral christãa e a civilisação moderna - para não perpetrarem-se actos de barbaria. A lei da guerra - consiste pois no complexo das restricções eslabelecidas entre as Nações civilisadas para n'ella empregar-se sómente os meios necessarios ao seu fim, e não actos de barbaridade, muitas vezes inuteis, injustos e immoraes ou contrarios à lei natural. A guerra é um mal inevitavel; tem suas leis como a paz" (DRUMMOND, Antonio de Vasconcellos Menezes de. Preleç̧ões de direito internacional: com referencia e applicação de seus princípios a's leis particulares do brasil até 1867. Recife: Typographia do Correio do Recife, 1867.).

5 KOLB, Robert. The protection of the individual in times of war and peace. In: THE OXFORD Handbook of the History of International Law. New York: Oxford University Press, 2014, p. 317-337. p. 321. 
of the armed conflict', a change influenced by the human rights movement". ${ }^{6-7}$ After revisiting such encounter, we investigate some of its consequences.

Fundamental norms of international humanitarian law, such as the distinction between combatants and non-combatants, the protection of civilians, the right of prisioners of war to a human treatment, the prohibition of the use of biological and chemical weapons, are widely accepted. Though such principles are frequently violated in the battlefield and there is heated disagreement on many norms of humanitarian law instruments, as on those concerning occupation, 194 states ratified the Geneva Conventions of 1949 - one more than the total of UN members - and 172 and 166 states also ratified Protocols I and Additional Protocols II of 1977 Additional to the four Geneva Conventions, respectively. ${ }^{8}$ Some of the most popular human rights instruments, as the 1948 Convention on the Prevention and Punishment of the Crime of Genocide, the 1966 International Covenant on Civil and Political Rights and the 1984 Convention against Torture, have less acceptance than the ones on humanitarian law, with 142, 167 and 153 parties, respectively.

Just as human rights, the rules, principles and categories of international humanitarian law integrate our vernacular language. Domestic and human rights courts, as the U.S. Supreme Court in cases concerning the so-called illegal combatants or the Inter-American Court on $\mathrm{Hu}-$ man Rights in the Gomes Lund case, invoke international humanitarian norms to decide about sensitive national matters. Humanitarian law also is increasingly present in broadcasts and printed media, not only in the United States and European countries, but also in Latin American ones. Contemporaneously civilians and military targets sound so natural to our ears that one loses sight of how recently these terms came to be part of the language that ordinary people use to describe events, to think about human affairs and to formulate claims for social change.

\footnotetext{
${ }^{6}$ MERON, Theodor. The bumanization of international law. The Hague: Martinus Nijhoff Publishers, 2006

It was after the second half of the $20^{\text {th }}$ century that the expression 'humanitarian law' began to be used in lieu of earlier expressions. Such change was "fashionable" in circles around the Red Cross, according to Schwarzenberger (SCHWARZENBERGER, Georg. From the Laws of War to the Law of Armed Conflict. Current Legal Problems, v. 21, n. 1, p. 239-258, 1968. p. 250).

8 It is noteworthy that neither US nor Israel are party of the 1977 Protocols. Available at: http://www.icrc.org/ihl.nsf/ INTRO?OpenView. Access in: 2 Jan. 2020.

9 See: http:/ $/$ treaties.un.org $/$ pages $/$ Treaties.aspx:id $=4 \&$ subid=A\&lang=en. Access in: 2 Jan. 2020.
}

International humanitarian law definitely became popular. Its popularity nonetheless does not assure either the accomplishment of its aims, or greater consensus on the meaning of its norms. Rather the opposite, the more far-reaching the circulation of humanitarian norms is, the more disputed their meaning seems to get. The unfolding events of $9 / 11$ have been a milestone in the vernacularization of humanitarian law. ${ }^{10}$ Based on the decision to consider the war against al-Qaeda neither an international conflict nor a internal conflict and to interpret the category 'non-international conflict' restrictively, the politics of war of the United States brought to the fore the capacity of international law to cope with current armed conflicts, particularly the ones against transnational groups. International humanitarian law then became a matter of concern and public debate in local contexts that were crossed by human rights, taken not only as juridical norms, but mainly as part of vernacular language, that is, as cultural norms.

In this article, we intend to shed light on the encounter of humanitarian law with human rights, illuminating specially its effects on the state power. We argue that the emergence of human rights as a language of political transformation has had a crucial impact on humanitarian law. Their rise would have created favorable conditions for humanitarian norms to reclaim their place in law and politics, whereas making them more open both to criticisms regarding their efficience and to abusive uses by states.

The article is divided in four parts. After this introduction, the following section discusses how humanitarian norms were advanced in the $19^{\text {th }}$ century within a formal framework that demanded rigid categories. The third section deals with the emergence of human rights vis-à-vis humanitarian law. Finally, the forth part raises some consequences of this process.

\section{Drawing humanitarian lines in the $19^{\text {th }}$ century}

In the European nineteenth century, liberal ideas traced from the Enlightenment such as order, reason and civilisation became desires and arguments alongside practices of Empire and violence elsewhere. European

\footnotetext{
10 For a research based on archival work, see: MOYN, Samuel. From Antiwar Politics to Antitorture Politics. In: LAW and War. Stanford: Stanford University Press, 2014, p. 154-197.
} 
jurists nurtured a vague notion of Rule of Law, and international law was highly regarded as a (political) project that could extract legal procedures from politics and diplomacy whilst claims to departure from the former and absorb the latter. "The fight for an international Rule of Law", writes Koskenniemi, "is a fight against politics, understood as a matter of furthering subjective desires and leading into an international anarchy". ${ }^{11}$

Perhaps one of the best illustrations of such endeavour is the work of Johann Caspar Bluntschli (18081881), a Swiss lawyer and one of the founders of the organisation that embodied this spirit of the time, the Institut de Droit International. To Bluntschli, international law constrained state sovereignty to "maintain peace and civilise war" with rules. ${ }^{12}$ Yet, for it to work, the relations between sovereigns had to be orchestrated by law rather than politics. For him, relations disciplined through legal rules alongside the Rule of Law in the international sphere could result in order and civilisation.

Calls for a codification of international law circulated amongst jurists such as Bluntschli and others. ${ }^{13}$ They seem to share the belief that ordering international rules regulating state behaviour would favour ordering their life in the international sphere. ${ }^{14-15}$ If law was going to play a crucial role in restraining and organising war, it was essential to pose international legal defini-

11 KOSKENNIEMI, Martti. The politics of international law. European Journal of International Law, v. 1, 1990. p. 5.

${ }_{12}$ According to Bluntschli, "un état ne peut pretender qu’à l'indépendance et à la liberté compatibles avec l'organisation nécessaire de l'humanité, avec l'indépendance des autres états et avec les liens qui unissent les états entre eux. 1. Le droit international maintient et restreint à la fois la souveraineté des états, parce qu'il cherche à maintenir la paix et civilise la guerre en la réglementant. Aucun état ne peut, contre le droit international, faire appel à sa souveraineté, parce que le droit international a pour base, non pas le bon plaisir des états, mais les droits et les intérêts généraux de l'humanité." (BLUNTSCHLI, Johann Caspar. Le droit international codifié. Paris: Libraire de Guillaumin, 1895, p. 66).

13 On this matter see: KENNEDY, David. International law and the nineteenth century: history of an illusion. Nordic Journal of International Law, v. 65, n. 3, p. 385-420, 1996.

14 The codification initiatives crossed into the $20^{\text {th }}$ century and represent a powerful positivist approach to international law. Examples range from the Bustamante Code (1928) to art. 13(1)(a) of the UN Charter. For a study on an early proposal of an International Law Code from the Brazilian jurist Epitácio Pessoa, see: FRANCA FILHO, Marcílio Toscano; MIALHE, Jorge Luís; JOB, Ulisses Silveira. Epitácio pessoa e a codificação do direito internacional. Porto Alegre: Sergio Antonio Fabris, 2013.

15 For a comprehensive study on the matter, see: DE VISSCHER, Charles. La codification du droit international. Recueil des Cours, v. 6, p. $325-472,1925$. tions and categories such as 'peace', 'conflict', 'battlefield', 'civilians', and 'combatants'. The jurists in the late $19^{\text {th }}$ century agreed on two distinct sets of ideas: "a humanitarian moral conviction that the forces of peace stand outside war, demanding that swords be beaten into ploughshares, and a legal project to sharpen the distinction between public powers and private rights. The result was a legal conception of war as a public project 'limited to its sphere"'. ${ }^{16}$

Current understandings of humanitarian law as part of a framework committed to the protection of the human person in times of armed conflict is distant from the arguments made at late $19^{\text {th }}$ century conferences and documents. Nonetheless, alongside their desire to foster an international Rule of Law, the liberal international lawyers of the late $19^{\text {th }}$ century struggled with the persistent phenomenon of war. If they overwhelmingly opposed war "as a manifestation of the primitive and destructive instincts that it was the point of law to eradicate from civilized life", at the same time, "they were equally averse against utopians who failed to see that war was occasionally needed to change an obsolete situation or was an enforcement against the law-breaker". ${ }^{17}$ The laws of war did not operate in spite of such duality, quite the opposite: they rested upon it. On the one hand, as civilisation was not evolved enough to curtail wars, international lawyers argued, its barbarianism at least ought to be fought. International law would play a vital role in their attempt to control war, even if it was for a restricted Western group of nations. On the other hand, jurists from the $19^{\text {th }}$ century also understood the need to favour military rationale over the humanitarian one. The notion of 'military necessity' endorsed by the early documents and treaties allowed more than they prohibited: the laws of war equally legitimised the belligerent's violent conduct. ${ }^{18}$

The unsettling combination of humanitarianism and militarism is captured in the early international law textbooks not only from Europe but also mimicked at fringes of the ius publicum europaeum. The brief mention mention of Menezes de Drummond's reading of the

\footnotetext{
16 KENNEDY, David. Of war and law. Princeton: Princeton University Press, 2006. p. 66.

17 KOSKENNIEMI, Martti. The gentle civilizer of nations: the rise and fall of international law 1870-1960. New York: Cambridge University Press, 2001. p. 83.

18 NORMAND, Roger; JOCHNICK, Chris Af. The legitimation of violence: a critical analysis of the Gulf war. Harvard Journal of International Law, v. 35, n. 1, p. 49-95, 1994.
} 
Paraguayan War in the beginning of thus article is an example. A similar appraisal can be found in other canonic texts, such as the work of famous Argentinean jurist Carlos Calvo (1824-1906). To him, it is a general principle in the laws of war "that no cultured nation should use means or instruments of war that produce a useless effusion of blood", what did not mean that "modern peoples have to renounce warrior art developments and the reform of its armaments, which marching in consumption with civilisation are under new, albeit terrible modifications". ${ }^{19}$

The nineteenth century conferences and treaties combined humanitarian cries for limits on human suffering and broad permissions for 'necessary' military action. Both features are present in the 1864 Geneva Convention, the 1868 Declaration of St. Petersburg, the Brussels Conference of 1874, the 1880 Oxford Manual and The Hague Conventions of 1899. Whether one understands them as 'hallmarks' of current humanitarian law $^{20}$ or as 'failures' and guided by a military logic, ${ }^{21}$ these instruments aimed at settling clear rules of engagement. Even if they left room for the political manoeuvres with the notion of 'military necessity', they were drafted with a formalistic mindset. When assessing the development of the law throuought the century, a Brazilian jurist of the $19^{\text {th }}$ century hailed the 1864 Geneva Convention: it had "greatly civilised war". 22 Precise and straightforward rules were the right direction.

The calls in the second half of the $19^{\text {th }}$ century for drafting international norms and principles applicable during warfare did not mean a displacement of the state either in political and legal theory or in political practi-

\footnotetext{
19 "como principio general en esta materia puede asentarse el de que ninguna nacion culta debe servirse de medios o instrumentos de guerra que produzcan una efusion inútil de sangre, sin que eso quiera decir, que los pueblos modernos hayan de renunciar a los adelantos en el arte guerrero y a la reforma de sus armamentos, que marchando de consumo con la civilizacion sufren nuevas, aunque terribles modificaciones" (CALVO, Carlos. Derecho Internacional Teórico y Prático de Europa y América. Paris: A. Durand et Pedone-Lauriel, 1868. v. 1. p. 392).

20 KOLB, Robert. The protection of the individual in times of war and peace. In: THE OXFORD Handbook of the History of International Law. New York: Oxford University Press, 2014. p. 317-337. 21 NORMAND, Roger; JOCHNICK, Chris Af. The legitimation of violence: a critical analysis of the Gulf war. Harvard Journal of International Law, v. 35, n. 1, p. 49-95, 1994. p. 66 and 76.

22 "Civilizou-se muito a guerra. A Convenção de Genebra de 1864 pôs em prática a regra: Hostes, dum vulnerati, fratres" (LESSA, Pedro Augusto Carneiro. O direito no século XIX. Revista da Faculdade de Direito de São Paulo, São Paulo, v. 8, p. 161-207, 1900. p. 194)
}

ces. On the contrary: the idea of sovereignty remained central to the international legal order and to the $19^{\text {th }}$ century political kosmos when the early documents brought into light some of what the orthodox historiography claims to be the fundamental humanitarian norms. The spread of a radical readings of liberal ideas faced resistance from those who opposed any attempts to locate the esprit d'internationalité outside the state. It was a common opinion among jurists that the competencies of the sovereign derived from the sovereign itself, not from an exogenous morality or any other political authority. ${ }^{23}$ The sovereignty of a nation is "nothing but its own will", wrote the Brazilian jurist Lafayette Rodrigues Pereira (1834-1917), to whom international law was the result of the common will of nations. ${ }^{24}$ Amidst competencies of the sovereign were the police power at the domestic level and the warfare at the international one. The legal regulation of war (a long step away from the previous Clausewitzian tradition of war and politics) defined the boundaries of action of the states against each other based on what was prohibited (hence, also what was permissible), but it also strengthened their authority towards their citizens and non-citizens in their territories once international law described one sole legitimate way of combating: as a state. Besides, the sovereign remained the only one who could create and chose to be bound by such rules. "From the notion of war", Rodrigues Pereira wrote, "one clearly infers that the only one who has the capacity to make it are sovereign and independent nations, who are the subjects of international law". 25

Despite the efforts for a general law of armed conflict framework, the architects of the post world wars in the $20^{\text {th }}$ century surrounded international law with disbelief, especially regarding its ability to regulate political and military power while claiming to be outside politics. ${ }^{26}$ This disbelief would have been stronger after

\footnotetext{
23 This doctrine was very much influenced by the German tradition of international legal thinking, especially from 1871 to 1933. On this matter, see chapter 3 of Martti Koskenniemi's Gentle Civilizer.

${ }^{24}$ "A soberania da nação não é senão a sua propria vontade". (PEREIRA, Lafayette Rodrigues. Princípios de direito internacional. Rio de Janeiro: Jacintho Ribeiro dos Santos, 1903. t. 1. p. 24)

25 "Da noção de guerra deprehende-se claramente que só tem capacidade para faze-la as nações soberanas e independentes - as que são pessoas do Direito Internacional”. (PEREIRA, Lafayette Rodrigues. Princípios de direito internacional. Rio de Janeiro: Jacintho Ribeiro dos Santos, 1903. t. 2. p. 62).

26 Classic examples are E. H. Carr's The Twenty Years' Crisis (1939)
} 
the Second World War. If the 1928 Briand-Kellogg Pact outlawing war still can be seen as a demonstration of faith in international law, in the aftermath of the Second World War jurists found themselves in the delicate position of having to persuade world leaders and diplomats of the importance of international law and to provide a formal regulation to the world.

Because of such general disbelief, jurists devoted their energy, talents and knowledge to find a role for the law in the new order, instead of insisting on styling an organisation to control power through rules. One possibility was conferring a stronger role to judicial institutions, as advocated (albeit differently) by Hersch Lauterpacht (1897-1960) in the 1930s ${ }^{27}$ and Hans Kelsen (1881-1973) in the 1940s. ${ }^{28}$ The focus on the intrinsic value of legal norms shifted to its use, whereas effectiveness and, later, persuasiveness replaced validity as a criterion for legality. ${ }^{29}$ One effect of such change has been that conventional lines separating law, morality, and politics that the $20^{\text {th }}$ century inherited from the late $19^{\text {th }}$ became gradually blurred in legal reasoning. The indeterminacy of such spheres created conditions for the moralization of international politics, the legalization of morals at the international level, and the politicization of international law.

The shift to the use of international law, instead of focusing the value of its norms, or, in other words, the shift from a formalistic mindset to an instrumentalist one, profundly affected international humanitarian law. Throughout the second half of the $20^{\text {th }}$ century, military personnel took active part in the negotiations of international humanitarian instruments under the pretext that this could facilitate its compliance. Indeed, as we learned from the U.S. war against terrorism, ${ }^{30}$ military personnel can hold stronger commitments to the laws of war than civil public servants for humanitarian or

and Hans Morgenthau's Politics Among Nations (1946).

27 LAUTERPACHT, Hersch. The function of law in the international community. New York: Oxford University Press, 2011.

28 KELSEN, Hans. Peace through law. New Jersey: The Lawbook Exchange, Ltd., 2000.

29 According to Kennedy, to think that a certain norm is 'valid' is to consider that it was promulgated by the proper institution and the correct procedure or if it can be deduced by legitimate means and interpreters. KENNEDY, David. Of war and law. Princeton: Princeton University Press, 2006. 91-92

30 NAGAMINE, Renata Reverendo Vidal Kawano; RORIZ, João Henrique Ribeiro. O combatente inimigo no debate sobre a condução da guerra dos Estados Unidos contra o terrorismo. Revista brasileira de ciências criminais, n. 120, p. 329-377, 2016. utilitarian reasons, but bringing them to the negotiation table resulted in international legal norms less ambitious than humanitarian advocates expected. These advocates supported such agreements, and began to invest their energies and resources to expand the constraints on the use of force beyond what was agreed upon on treaties. Their strategy has been portraying international norms in a more persuasive way in the public debate, which often means invoking moral arguments to support readings of international norms more conforming to the grammar of the public arena. As legal scholar David Kennedy argues, the clear and straightforward rules drafted throughout the $19^{\text {th }}$ century thus become principles and customs, or general patterns whose enforcement depends on the circumstances, i.e., on politics. In such public battle to define the boundaries of international legal categories, the military responds to the moral argument sponsored by humanitarians with national interest rhetoric. ${ }^{31}$ During the cold war, national security and, consequently, military necessity arguments were widely acceptable in international relations and in national societies, but their acceptance begins to wane as human rights rise and create conditions for the emergence of humanitarian law.

\section{Humanitarian law meets human rights}

The rise of human rights has been seen as a remarkable feature of the $20^{\text {th }}$ century, and intellectuals from different fields have dedicated efforts to its study from diverse perspectives. The emergence of a strong rights language among $20^{\text {th }}$ century utopias has been timely pointed by Claude Lefort in his 1979 essay Droits de l'homme et politique and studied by the Brazilian sociologist Luciano Oliveira in his doctoral thesis developed under Lefort supervision at the École des Hautes Études. Good examples from the legal field are texts from Hersch Lauterpacht (e.g., International Law and Human Rights, 1950) and Louis Henkin (e.g., The Rights Of Man Today, 1978). From the International Relations field, the phenomenon has been researched mainly from the constructivist perspective, such as the work from Margaret Keck and Kathryn Sikkink (e.g., Activists beyond

\footnotetext{
KENNEDY, David. Of war and law. Princeton: Princeton University Press, 2006. p. 84-88.
} 
Borders, 1998) and Thomas Risse, Stephen Ropp and Sikkink (e.g., The Power of Human Rights, 1999). More recently, it has been analysed by the intellectual historian Samuel Moyn in his provocative The Last Utopia.

Understanding human rights as a frame to social mobilisation, Moyn claims that the rise of human rights has been possible due to the disbelief in competing utopias, particularly, socialism, anticolonialism, and nationalism in the late 1960s and 1970s. Leftist activists and social movements in Eastern Europe were discouraged to reform their regimes, whereas the ones in Latin America were unsuccessful in leading revolutions. The upsurge of internal conflicts and authoritarian regimes in decolonised territories in turn discredited the state as the sole incubator of rights. Moyn argues that in the second half of the 1960s disappointment stroke politics in general and created conditions for the abstract norms of human rights to emerge as a moral and an anti-politics frame, vehicles of moral progress. This new understanding and use of rights did not sit easy with traditional international law, and its sovereignist core. A number of jurists such as Henkin in the US (and we could add Antonio Augusto Cançado Trindade and Carlos Nino in Brazil and Argentina, respectively) advocated for a turn in the discipline, one that would leave its statist focus behind.

Human rights then met international law and, for Moyn, the former vested the later with a once lost authority that was responsible for its resurgence in the $20^{\text {th }}$ century. ${ }^{32}$ To the historian, "peripheral before as a widespread framework for improvement, international law is perhaps the prime beneficiary of the recent crisis and recasting of utopian aspirations". ${ }^{33}$ Throughout the 1970s and part of the 1980s, human rights were anti-totalitarian and committed to the protection of the individual against the state, features now commonly attributed to be the "purpose" or "function" of interna-

\footnotetext{
32 Martti Koskenniemi (The Gentle Civilizer of Nations, 2001) and Samuel Moyn (The Last Utopia, 2010) read differently the political projects of international law in the second half of the $20^{\text {th }}$ century. While the Finnish lawyer believes that international law as a language capable of making sense of the world declined around the 1960s, the American historian understands that it rose again during the 1970s, with human rights at its core. For more on this, see: RORIZ, João. Direitos Humanos como um novo projeto para o direito internacional: notas sobre the Last Utopia, de Samuel Moyn. Brazilian Journal of International Law, v. 15, n. 2, p. 490-496, 2018.

33 MOYN, Samuel. The last utopia. Cambridge, MA: Harvard University Press, 2010, p. 176.
}

tional law itself. ${ }^{34}$

Similarly, humanitarian law did not thrive at once. The brief momentum of enthusiasm with it after the Second World War that culminated in the draft of the 1949 Geneva Conventions, dwindled in the anxieties of the cold war and the imminent possibility of the outbreak of a nuclear war. In the face of nuclear threat and the wars of national liberation turned into proxy wars by Great Powers, anti-war politics marked the late 1960s and early 1970s. During this period, and despite the Vietnam War, the idea of addressing atrocity did not become a central issue to pacifism, nor inspired a movement to discuss it. ${ }^{35}$ Even amongst jurists the struggle remained more about ending wars and fostering peace than making them less 'barbaric'.

Jus in bello and jus ad bellum were turned into strange bedfellows in the post-Second World War order. The UN Charter prohibited the use of force in international relations if not in self-defense or authorized by the Security Council, but no words were dedicated to the conduct of hostilities. Unlike human rights, humanitarian law was not mentioned in the Charter and remained a separated issue discussed in different diplomatic meetings. whereas humanitarian law regulated the use of force, determing how and when it could be used according to international law. International human rights law instruments, in tandem with legal and political institutions dedicated to their implementation, and the challenges brought by the anti-colonial wars, account for changes in its corpus juris. Some initiatives could be numbered. One could mention among them the regulation of non-international conflicts by commom article 3, the 1968 Teheran Resolution prescribing human rights norms to be applied in armed conflicts and the agreement on the understanding that national liberation wars should be considered international conflicts. Nevertheless, none of those reasons can explain how humanitarian norms came to be part of our vernacular language.

We understand that the novel human rights appeal to mobilise social movements to political action made the detachment of activists from pacifism possible by definitely changing the law to which individuals owed

\footnotetext{
34 MOYN, Samuel. From Antiwar Politics to Antitorture Politics. In: $L A W$ and War. Stanford: Stanford University Press, 2014, p. 154-197.

35 I MOYN, Samuel. From Antiwar Politics to Antitorture Politics. In: $L A W$ and War. Stanford: Stanford University Press, 2014, p. 154-197.
} 
obedience. ${ }^{36}$ Human rights as advocated from the liberal perspective from the 1970s onwards empowered the individual against the state and since it promoted the international sphere it also displaced the state as a preferential reference to utopian claims. Pacifists that could not efficaciously pressure states to respect the UN Charter soon began to turn to human rights in order to circumscribe their freedom to choose means and methods of combat. The conduct of armed conflicts becomes a primary concern for them once they realise how useless it had been to mobilise against their outbreak. ${ }^{37}$ Thus, humanitarian law came to be part of the civil lexicon human rights activists would have to be liberated from concerns with anti-totalitarianism and pacifists from both the imminence of a nuclear war and from the faith that social action can prevent states to recourse to armed force. Along this line of thought, the entanglement of human rights and humanitarian law to political purposes results from a political process that outdates the formal convergence between them.

A number of factors might have contributed more directly for the vernacularizaton of international humanitarian law. One example is the processes of transitional justice in Latin America due to the fact that activists began to claim for accountability for acts of torture and to frame their demands as crimes against humanity. Another is its use by activists and other political actors in the United States to overcome the suspicion that then president Ronald Reagan nurtured with regards to human rights. A decisive step was the institution of the International Criminal Tribunals for the former Yugoslavia (ICTY) and for Rwanda (ICTR) by the Security Council in the first half of the 1990s. One of the best examples is the early ICTY jurisprudence, specially the Tadic case. ${ }^{38}$ The ascendancy of humanitarian law as a vernacular language used in political struggle to claim for social change therefore would result from its reading according to the human rights grammar and as part of the human rights morality.

\footnotetext{
36 SHKLAR, Judith N. Legalism: law, morals, and political trials. Cambridge, MA: Harvard University Press, 1986.

37 MOYN, Samuel. From Antiwar Politics to Antitorture Politics. In: $L A W$ and War. Stanford: Stanford University Press, 2014, p. 154-197.

38 NAGAMINE, Renata R. V. K. O Tribunal para a antiga Iugoslávia na formação da norma da responsabilidade individual por graves violações de direitos humanos: tensões entre direitos humanos e princípios penais liberais. Espaço Jurídico Journal of Law, v. 17, n. 3, p. 779-796, 2016.
}

It is interesting to recall that in his The Last Utopia, Moyn argues that, throughout the decades, human rights had turned from a minimalist, anti-totalitarian frame into a maximalist one; and indeed, if we analyse the 1993 Vienna Conference, we can note that human rights has been associated with different projects, from civil and family rights to development issues. One can add to Moyn's argument that, in the process of becoming a maximalist frame, human rights also became more contested and less universal. Their rise as a utopia thereby inaugurated its waning as a universal pattern, culminating in their emergence as relative norms in the 1990s. Not only political scientists and philosophers now engage in public debate on the universality or relativity of human rights - and one sees renewed theoretical efforts to construe the universality of their fundamentals -, but also some international norms are proposed, as humanitarian intervention and late in the decade the notion of 'responsibility to protect'. 39

As humanitarian law becomes part of the currently available talk about human affairs, it begins to be used to describe social phenomena in wider and more different political arenas. This means, inter alia, that humanitarian norms begin to be applied in local contexts and hence be appropriated by local actors. To use international norms for social mobilization in local contexts human rights and humanitarian activists not only apply, but also interpret them. In other words, they also create meaning, they signify them.

\section{From limits to authorization?: state action in legal indeterminacy}

In this section, we argue that in situations in which the set of applicable norms is unclear and there is a larger room for legal indeterminacy, legal definitions become blurred and this gives room for abuse. Notably, we understand that international human rights law may in some cases enable the state to use its sovereign powers with minimal constraints in the suppression of political opposition and that humanitarian norms are relegated in such process.

The entanglement between humanitarian law and

ORFORD, Anne. International authority and the responsibility to protect. New York: Cambridge University Press, 2011. 
human rights became evident when specific cases were dealt with, and a need for coherence in legal argumentation was deemed crucial. In the 1996 Nuclear Weapons advisory opinion, the International Court of Justice provided some unity between the two set of laws. To the judges in The Hague who were involved with the case human rights law could also be applicable during armed conflicts and humanitarian law could be interpreted as its lex specialis, ${ }^{40}$ what generated some continuity between their norms. This reading has been restated in other cases..$^{41-42}$ To one commentator it was just after the advisory opinion that scholars broadly used the Latin expression to describe the relationship between the two set of laws, what suggests that such understanding of consistency is quite recent. ${ }^{43}$

One could hence assume that the linearity between them would mean that humanitarian norms should apply in situations when human rights are legally suspended. Nevertheless, there has been much room for debate.

Most human rights instruments provide space for exceptional situations, when certain rights can be suspended. According to article 4 of the International Covenant on Civil and Political Rights states parties must not endanger the lives of individuals nor subject them to torture or cruel, inhuman or degrading treatment. ${ }^{44}$

40 "In principle, the right not arbitrarily to be deprived of one's life applies also in hostilities. The test of what is an arbitrary deprivation of life, however, then falls to be determined by the applicable lex specialis, namely, the law applicable in armed conflict which is designed to regulate the conduct of hostilities. Thus whether a particular loss of life, through the use of a certain weapon in warfare, is to be considered an arbitrary deprivation of life contrary to Article 6 of the Covenant, can only be decided by reference to the law applicable in armed conflict and not deduced from the terms of the Covenant itself" (ICJ, Legality of the Threat or Use of Nuclear Weapons (Advisory Opinion)., p. 25)

${ }^{41}$ ICJ, Legal Consequences of the Construction of a Wall in the Occupied Palestinian Territory (Advisory Opinion).

42 ICJ, Case Concerning Armed Activities on the Territory of the Congo (DRC v. Uganda).

43 MILANOVIC, Marko. The Lost Origins of Lex Specialis. In: THEORETICAL Boundaries of Armed Conflict and Human Rights. New York: Cambridge University Press, 2016, p. 78-117.

44 "Article 4. (1) In time of public emergency which threatens the life of the nation and the existence of which is officially proclaimed, the States Parties to the present Covenant may take measures derogating from their obligations under the present Covenant to the extent strictly required by the exigencies of the situation, provided that such measures are not inconsistent with their other obligations under international law and do not involve discrimination solely on the ground of race, colour, sex, language, religion or social origin. (2) No derogation from articles 6, 7, 8 (paragraphs I and 2), 11, 15,
The European ${ }^{45}$ and American ${ }^{46}$ human rights conventions have similar provisions, and the prohibition of torture is deemed absolute under the Convention against Torture of $1984 .{ }^{47}$ Human rights courts and institutions have addressed the issue. When assessing the applicability of habeas corpus in emergencies, the Inter-American Court of Human Rights understood that the obligation of states to recognise and respect rights and freedoms implies that they have the obligation to protect and ensure its exercise with guarantees to make them effective in all circumstances. According to the Court, the obligations to respect life and integrity, to prevent disappearances, and protect the individual against torture compel states to preserve the instrument

16 and 18 may be made under this provision. (...)"(UNITED NATIONS. International Covenant on Civil and Political Rights. Disponível em: https://www.ohchr.org/EN/pages/home.aspx. Acesso em: 4 jan. 2020.)

45 "Article 15. Derogation in time of emergency. (1) In time of war or other public emergency threatening the life of the nation any High Contracting Party may take measures derogating from its obligations under this Convention to the extent strictly required by the exigencies of the situation, provided that such measures are not inconsistent with its other obligations under international law. (2) No derogation from Article 2, except in respect of deaths resulting from lawful acts of war, or from Articles 3, 4 (paragraph 1) and 7 shall be made under this provision"(COUNCIL OF EUROPE. Convention for the Protection of Human Rights and Fundamental Freedoms. Disponível em: https://www.echr.coe.int/Documents/Convention_ENG.pdf. Acesso em: 4 jan. 2020).

46 "Article 27. Suspension of Guarantees (1) In time of war, public danger, or other emergency that threatens the independence or security of a State Party, it may take measures derogating from its obligations under the present Convention to the extent and for the period of time strictly required by the exigencies of the situation, provided that such measures are not inconsistent with its other obligations under international law and do not involve discrimination on the ground of race, color, sex, language, religion, or social origin. (2). The foregoing provision does not authorize any suspension of the following articles: Article 3 (Right to Juridical Personality), Article 4 (Right to Life), Article 5 (Right to Humane Treatment), Article 6 (Freedom from Slavery), Article 9 (Freedom from Ex Post Facto Laws), Article 12 (Freedom of Conscience and Religion), Article 17 (Rights of the Family), Article 18 (Right to a Name), Article 19 (Rights of the Child), Article 20 (Right to Nationality), and Article 23 (Right to Participate in Government), or of the judicial guarantees essential for the protection of such rights." (ORGANIZATION OF AMERICAN STATES. American Convention of Human Rights. Disponível em: https://www.cidh.oas.org/basicos/english/ basic3.american\%20convention.ht. Acesso em: 4 jan. 2020.)

47 "Article 2 (2). No exceptional circumstances whatsoever, whether a state of war or a threat of war, internal political instability or any other public emergency, may be invokd as a justification of torture." (UNITED NATIONS. Convention against torture and Other Cruel, Inbuman or Degrading Treatment or Punishment. Disponível em: https://www.ohchr.org/en/professionalinterest/pages/cat.aspx. Acesso em: 4 jan. 2020 
of the habeas corpus even when there is a suspension of guarantees. ${ }^{48}$ When facing a similar question, the European Court of Human Rights created some procedural guidelines to address it. The court distinguished threats to "life of the nation", from those that threatens "public order", and sets limits to the advancement of state power on the human rights. The danger that threatens the life of the nation also allows derogation of the most fundamental rights, while the danger threatening public order would open exhaustively listed exceptions (articles 2 and 5 of European Convention) and restrictions (articles 8 to 11). Most importantly, the Court would control the respect to the legal framework as a whole and the proportionality of State measures, distinguishing measures as (i) timely or reasonable (art. 5), (ii) absolutely necessary (art. 2 (2)), (iii) strictly necessary (art. 6 (1)), and the (iv) strictly necessary measure required by the situation (art. 15)..$^{49}$ At the UN level, the General Comment N. 29 (2001) (that replaced the General Comment N. 5 from 1981), states that the maintenance of procedural guarantees is inherent to the protection of non-derogable rights, and that the protection against arbitrary detention incidentally also protects against ill-treatment, inhuman treatment and torture. The Comment also considers that the peremptory human rights norms extend beyond the provisions enroled in Article 4 (2) of the 1966 Pact. States cannot, according to it, rely on their laws to justify an act that violates international humanitarian law or jus cogens, such as arbitrary detention and deviations from the fundamental principles of a fair trial. ${ }^{50}$

Such understandings pose limits to states but at the same time give them space for manoeuvre in other circumstances in accordance with human rights norms and not necessarily covered by humanitarian law. When balancing more flexible norms and principles other considerations (such as security) may play a role. Detention has been an example, especially after $9 / 11$. When dealing with it, the European Court understood that to be

${ }_{48}$ INTER-AMERICAN COURT OF HUMAN RIGHTS. El habeas corpus bajo suspensión de garantías (Opinión Consultiva OC-8/87). Disponível em: http://www.corteidh.or.cr/docs/opiniones/seriea_08_esp.pdf. Acesso em: 4 jan. 2020.p. 35.

49 DELMAS-MARTY, Mireille. Libertés et sûreté dans un monde dangereux. Paris: Le Seuil, 2010. p. 158-159.

50 UN HUMAN RIGHTS COMMITTEE. CCPR General Comment No. 29: Article 4: Derogations during a State of Emergency (CCPR/C/21) Rev.1/Add.11). Disponível em: https://www.refworld.org/ docid/453883fd1f.html. Acesso em: 4 jan. 2020. legal, detention ought to be in agreement with domestic legislation and cannot be contrary to the Convention. Detention must be linked to the reasonings put forward by the government, must offer means so that the defendant can contest it, must be implemented under appropriate conditions, and with a duration that does not exceed its purpose. ${ }^{51}$ Nonetheless, despite its continued effort to delineate notions and set parameters, the European Court already broadened its understanding in cases involving terrorism:

46. The Court has found in previous cases that detention on remand exceeding five years constituted a violation of Article $5 \mathbb{S}$ of the Convention [references omitted].

47. The present case involved a particularly complex investigation and trial concerning serious offences of international terrorism which caused the death of three victims and serious suffering to more than a hundred. Following his extradition from Lebanon in 1996, the sole reason for the applicant's presence in Germany was to stand trial for these offences.

48. In these exceptional circumstances, the Court concludes that the length of the applicant's detention can still be regarded as reasonable. There has accordingly been no violation of Article 5 \ 3 of the Convention. ${ }^{52}$

Another example concerns definitions. When dealing with actual cases, the blind spots can mean space for bending norms and advancing other agendas. The boundaries between inhuman treatment and torture, for example, are quite blurred. International human rights law delineates what torture is, but does not present a definition of inhumane treatment. And the unclear limits between them has the practical effect of stressing a greater stigma on torture; after all the Convention demands States to criminalise only $i^{53}$ - leaving inhumane treatment aside. The European Court has decided that whereas the prohibition of ill-treatment is absolute, this does not mean that any sort of ill-treatment will be severe enough to prevent extradition or deportation as an

51 EUROPEAN COURT OF HUMAN RIGHTS. $A$ and Others v. The United Kingdom. Disponível em: http://hudoc.echr.coe.int/ eng?i=001-91403. Acesso em: 4 jan. 2020. p. 184.

52 EUROPEAN COURT OF HUMAN RIGHTS. Chradi v. Germany. Disponível em: http://hudoc.echr.coe.int/eng?i=001-77694. Acesso em: 4 jan. 2020.

53 "Article 4 (1) Each State Party shall ensure that all acts of torture are offences under its criminal law. The same shall apply to an attempt to commit torture and to an act by any person which constitutes complicity or participation in torture." (UNITED NATIONS. Convention against torture and Other Cruel, Inbuman or Degrading Treatment or Punishment. Disponível em: https:/ /www.ohchr.org/en/ professionalinterest/pages/cat.aspx. Acesso em: 4 jan. 2020.) 
inhumane treatment. ${ }^{54-55}$ In light of such understanding, the Court understood that the European Convention should not be a means by which its state parties impose conventional standards to non-state parties, and ultimately recognises that it will rarely conclude for the impossibility to extradite or deport to a state with democratic, human rights, and rule of law traditions. To complicate things further, the very existence of those limits in humanitarian law would be uncertain, given that its framework does not define inhuman treatment or torture and does not offer criteria to establish levels of gravity among prohibited practices.

In another case and court, judges decided to use the human rights reasoning to introduce a definition of torture in the field of humanitarian law. They used the 1984 Convention definition on torture when applying humanitarian norms - even though the convention itself establishes that it does not have extraconventional reach. The judges at the International Criminal Court for the former Yugoslavia understood in the Kunarac case that the prohibition on torture is customary and peremptory for criminal liability purposes, even if its definition is not. This opened space for international criminal courts to propose a definition of torture more alligned with humanitarian law. With a human rights customary law inference, the ICTY judges expanded the notion of torture given by human rights instruments: the "official capacity" requirement of the agent ${ }^{56}$ was dropped. ${ }^{57}$

54 EUROPEAN COURT OF HUMAN RIGHTS. $A$ and Others v. The United Kingdom. Disponível em: http://hudoc.echr.coe.int/ eng?i=001-91403. Acesso em: 4 jan. 2020. p. 126-127.

55 EUROPEAN COURT OF HUMAN RIGHTS. Babar Abmad and Others v. The United Kingdom. Disponível em: http://hudoc.echr. coe.int/eng?i=001-110267. Acesso em: 4 jan. 2020. p. 200-201.

56 The definition of torture present in the 1984 Convention requires a link with the state: "when such pain or suffering is inflicted by or at the instigation of or with the consent or acquiescence of a public official or otherperson acting in an official capacity." (emphasis added) (Article 1, UNITED NATIONS. Convention against torture and Other Cruel, Inbuman or Degrading Treatment or Punishment. Disponível em: https://www.ohchr.org/en/professionalinterest/pages/cat.aspx. Acesso em: 4 jan. 2020.)

57 "The Trial Chamber concludes that the definition of torture under international humanitarian law does not comprise the same elements as the definition of torture generally applied under human rights law. In particular, the Trial Chamber is of the view that the presence of a state official or of any other authority-wielding person in the torture process is not necessary for the offence to be regarded as torture under international humanitarian law."( INTERNATIONAL CRIMINAL TRIBUNAL FOR THE FORMER YUGOSLAVIA. Prosecutor v. Kunarac, Kovac and Vukovic, "Judgement", IT-96-23-T and IT-96-23/1-T. Disponível em: https://www. icty.org/x/cases/kunarac/tjug/en/kun-tj010222e.pdf. Acesso em:
Such decision supposedly had a "more protective" definition ${ }^{58}$ - more protective for the humanity, remains implicit, to the detriment of the defendant, who would benefit from the narrower definition.

This understanding of torture in international criminal courts, built in the jurisprudence from the pre-9/11 scenario, reveals a tension between the liberal criminal law tradition and the human rights influence on international criminal law with potential implications for the consequences for those accused of terrorism. In an article published before $9 / 11$, a commentator criticises the imprecise norms and the restrictions of rights of defendants on ad hoc criminal courts compared to those granted to them domestically. According to him, the imprecision and restriction would affect the modalities of guilt and the production of evidence. ${ }^{59}$ To another academic and former advisor to the ICC Prosecutor, the continuity between humanitarian law, human rights law, and international criminal law, as used by international criminal courts, could result in the removal of fundamental rights of the defendants, which are granted internally. This process could facilitate, for example, collective criminal responsibilization at the cost of individual procedural guarantees. Also, it could lead to the conclusion that whereas the defense of society by the state has limits, the defense of "humanity" has not. ${ }^{60}$ There is little (legal) sense and high margin for abuse in defending criminal guarantees and rights when it comes to advocate rights against the state and dropping them when international trial is in place.

The predisposition of states to frame dissidents and social movements as threats could be eased by such fra-

4 jan. 2020.) For a different approach see: Prosecutor v. Anto Furundzija (1998) ICTY IT-95-17/1-T, [151-153] [160-162].

${ }_{58}$ The ICTY judges understood that some elements represented customary law and with their reasoning they presented a definition of torture in the field of humanitarian law (para. 483). In their words: "On the basis of what has been said, the Trial Chamber holds that, in the field of international humanitarian law, the elements of the offence of torture, under customary international law are as follows: (i) The infliction, by act or omission, of severe pain or suffering, whether physical or mental. (ii) The act or omission must be intentional. (iii) The act or omission must aim at obtaining information or a confession, or at punishing, intimidating or coercing the victim or a third person, or at discriminating, on any ground, against the victim or a third person. (references omitted) (Ibid.).

59 SCHABAS, William A. Sentencing by international tribunals: a human rights approach. Duke Journal of Comparative \& International Law, v. 7, p. 461-517, 1997.

${ }^{60}$ ROBINSON, Darryl. The identity crisis of international criminal law. Leiden Journal of International Law, v. 21, n. 4, p. 925-963, 2008. 
mework, especially in times of a global "war on terror". Writing about the situation in India one month after 9/11, the activist Arundhati Roy warned that "governments across the world are cynically using the prevailing paranoia to promote their own interests" and that "all kinds of unpredictable political forces are being unleashed". She then describes how members of the All India People's Resistance Forum were jailed while distributing anti-war and anti-US pamphlets in Delhi, together with the printer of the leaflets. ${ }^{61}$ International law (including humanitarian and human rights) offers mixed possibilities for situations like these. The same treaties that could be instrumentalized to uphold political and civil liberties can also be used to advance 'expectional' measures by the state in times of trouble. After $9 / 11$, the expansion of criminal categories such as "terrorism" and other crimes supposedly against "national security" came at the cost of rights like freedom of association and expression, sometimes even without the necessary change of the provisions - just with different interpretations. ${ }^{62}$ Based on expanded limits, it was possible to establish "special procedures" to investigate and prosecute without new crimes. ${ }^{63}$

\footnotetext{
${ }_{61}$ ROY, Arundhati. "Brutality smeared in peanut butter". The Guardian, 2001. Disponível em: https://www.theguardian.com/world/2001/oct/23/afghanistan.terrorism8. Acesso em: 4 jan. 2020.

62 In a report from 2012, Human Rights Watch states that after 9/11 more than 140 governments have passed counterterrorism legislation as a response to a (possible) threat to the country, out of pressure from the USA or as a response to the Security Council resolutions after the attacks in New York and Washington. Such legislation also made it possible for states to have the legal tools to act against different social groups that include non-violence student organizations in India and in Turkey, journalists in Ethiopia, and ethinic minorities in the UK, among others (HUMAN RIGHTS WATCH. In the name of security: Counterterrorism laws worldwide since September 11. New York: HRW, 2012. Disponível em: https://www.hrw.org/sites/default/files/reports/global0612ForUploadFinal.pdf. Acesso em: 4 jan. 2020.)

63 Another example would be UN Security Council resolution 1373 , just after $9 / 11$. It decided that all states shall "criminalize the wilful provision or collection, by any means, directly or indirectly, of funds by their nationals or in their territories with the intention that the funds should be used, or in the knowledge that they are to be used, in order to carry out terrorist acts" and that anybody "who participates in the financing, planning, preparation or perpetration of terrorist acts or in supporting terrorist acts is brought to justice". Additionally that "such terrorist acts are established as serious criminal offences in domestic laws and regulations and that the punishment duly reflects the seriousness of such terrorist acts." This 'legislative' action by the Council demanded that all UN partystates must criminalize the finance of terrorism. As there is no consensual definition of terrorism in international instruments, it is up to the states to define the crime and to resort to its punitive power.
}

\section{Final remarks}

In this article, we analyse a certain encounter between human rights and humanitarian law. The novel interpretation of rights that arose in the 1970s with a particular frame largely influenced the laws of war in different directions. Distinct political actors began to use the legal vocabulary to organize social experience, to frame social problems, and to attribute responsibility. By interpreting such norms, those political actors lend them meanings that might compete against the ones produced in national and international institutions, which in matters of war and peace tend to interpret them more restrictively due to the interests of the states and, in the case of international institutions, to the balance that they must find in order not to jeopardise their authority. In a scenario of dissolving legal boundaries and fierce disputes of meaning, the encounter of human rights and humanitarian law also meant a revision of some of the traditional categories of the latter. The clear lines of humanitarian norms shouldered with abstract principles usage in real-life situations. The distinctions between categories such as war and peace, international and non-international conflict, civilian and military targets, combatants and non-combatants waned, giving more flexibility to decision makers and less protection to the most vulnerable.

The rise of human rights as a powerful normative language in international relations had significant implications for the ways in which law and politics are argued in this realm. As we tried to show with the encounter between human rights and humanitarian law, some of the broad and indeterminate features of rights principles and provisions might mean more room for abuse. The context in which states acts to address issues like terrorism and other perceived threats is rather complex. Some of its features include the increasing universality of human rights, and on a lesser scale, humanitarian law, as political languages as well as a persistent dispute around its meanings and categories. The alleged consensus around the necessity of a jus puniendi and the enforcement of normative categories involves the performance of not only international organisations related to criminal justice but also states. The particular language of rights might offer states a (normative)

(UNITED NATIONS SECURITY COUNCIL. Resolution 1373 (S/ RES/1373). Disponível em: https://www.unodc.org/pdf/crime/ terrorism/res_1373_english.pdf. Acesso em: 4 jan. 2020.) 
authority from the international level and, at the same time, empowers them with the requirement/liberty to incorporate such language shouldered with others such as national security.

\section{References}

BLUNTSCHLI, Johann Caspar. Le droit international codifié. Paris: Libraire de Guillaumin, 1895.

CALVO, Carlos. Derecho Internacional Teórico y Prático de Europa y América. Paris: A. Durand et Pedone-Lauriel, 1868. v. 1.

COUNCIL OF EUROPE. Convention for the Protection of Human Rights and Fundamental Freedoms. Disponível em: https:/ /www.echr.coe.int/Documents /Convention_ ENG.pdf. Acesso em: 4 jan. 2020.

DE VISSCHER, Charles. La codification du droit international. Recueil des Cours, v. 6, p. 325-472, 1925.

DELMAS-MARTY, Mireille. Libertés et sûreté dans un monde dangereux. Paris: Le Seuil, 2010.

DORATIOTO, Francisco. Maldita guerra: nova história da Guerra do Paraguai. 2. ed. São Paulo: Companhia das Letras, 2002.

DRUMMOND, Antonio de Vasconcellos Menezes de. Prelecções de direito internacional: com referencia e applicação de seus princípios a's leis particulares do brasil até 1867. Recife: Typographia do Correio do Recife, 1867.

EUROPEAN COURT OF HUMAN RIGHTS. $A$ and Others v. The United Kingdom. Disponível em: http:// hudoc.echr.coe.int/eng?i=001-91403. Acesso em: 4 jan. 2020.

EUROPEAN COURT OF HUMAN RIGHTS. Babar Abmad and Others v. The United Kingdom. Disponível em: http://hudoc.echr.coe.int/eng?i=001-110267. Acesso em: 4 jan. 2020.

EUROPEAN COURT OF HUMAN RIGHTS. Chradi v. Germany. Disponível em: http://hudoc.echr.coe.int/ eng?i=001-77694. Acesso em: 4 jan. 2020.

FRANCA FILHO, Marcílio Toscano; MIALHE, Jorge Luís; JOB, Ulisses Silveira. Epitácio pessoa e a codificação do direito internacional. Porto Alegre: Sergio Antonio Fabris, 2013.

HUMAN RIGHTS WATCH. In the name of security:
Counterterrorism laws worldwide since September 11. New York: HRW, 2012. Disponível em: https://www. hrw.org/sites/default/files/reports/global0612ForUploadFinal.pdf. Acesso em: 4 jan. 2020.

ICJ. Case Concerning Armed Activities on the Territory of the Congo (DRC v. Uganda).

ICJ. Legal Consequences of the Construction of a Wall in the Occupied Palestinian Territory (Advisory Opinion).

ICJ. Legality of the Threat or Use of Nuclear Weapons (Advisory Opinion).

INTER-AMERICAN COURT OF HUMAN RIGHTS. El habeas corpus bajo suspensión de garantías (Opinión Consultiva OC-8/87). Disponível em: http://www.corteidh. or.cr/docs/opiniones/seriea_08_esp.pdf. Acesso em: 4 jan. 2020.

INTERNATIONAL CRIMINAL TRIBUNAL FOR THE FORMER YUGOSLAVIA. Prosecutor v. Kunarac, Kovac and Vukovic, "Judgement", IT-96-23-T and IT96-23/1-T. Disponível em: https://www.icty.org/x/ cases/kunarac/tjug/en/kun-tj010222e.pdf. Acesso em: 4 jan. 2020.

KELSEN, Hans. Peace through law. New Jersey: The Lawbook Exchange, Ltd., 2000.

KENNEDY, David. International law and the nineteenth century: history of an illusion. Nordic Journal of International Law, v. 65, n. 3, p. 385-420, 1996.

KENNEDY, David. Of war and law. Princeton: Princeton University Press, 2006.

KOLB, Robert. The protection of the individual in times of war and peace. In: THE OXFORD Handbook of the History of International Law. New York: Oxford University Press, 2014. p. 317-337.

KOSKENNIEMI, Martti. The gentle civilizer of nations: the rise and fall of international law 1870-1960. New York: Cambridge University Press, 2001.

KOSKENNIEMI, Martti. The politics of international law. European Journal of International Law, v. 1, 1990.

LAUTERPACHT, Hersch. The function of law in the international community. New York: Oxford University Press, 2011.

LESSA, Pedro Augusto Carneiro. O direito no século XIX. Revista da Faculdade de Direito de São Paulo, São Pau- 
lo, v. 8, p. 161-207, 1900.

MERON, Theodor. The bumanization of international law. The Hague: Martinus Nijhoff Publishers, 2006.

MILANOVIC, Marko. The Lost Origins of Lex Specialis. In: THEORETICAL Boundaries of Armed Conflict and Human Rights. New York: Cambridge University Press, 2016, p. 78-117.

MOYN, Samuel. From Antiwar Politics to Antitorture Politics. In: $L A W$ and War. Stanford: Stanford University Press, 2014, p. 154-197. (Austin Sarat, Lawrence Douglas, Martha Umphrey).

MOYN, Samuel. The last utopia. Cambridge, MA: Harvard University Press, 2010.

NAGAMINE, Renata R. V. K. O Tribunal para a antiga Iugoslávia na formação da norma da responsabilidade individual por graves violações de direitos humanos: tensões entre direitos humanos e princípios penais liberais. Espaço Juridico Journal of Law, v. 17, n. 3, p. 779-796, 2016.

NAGAMINE, Renata Reverendo Vidal Kawano; RORIZ, João Henrique Ribeiro. O combatente inimigo no debate sobre a condução da guerra dos Estados Unidos contra o terrorismo. Revista brasileira de ciências criminais, n. 120, p. 329-377, 2016.

NORMAND, Roger; JOCHNICK, Chris Af. The legitimation of violence: a critical analysis of the Gulf war. Harvard Journal of International Law, v. 35, n. 1, p. 49-95, 1994.

ORFORD, Anne. International authority and the responsibility to protect. New York: Cambridge University Press, 2011.

ORGANIZATION OF AMERICAN STATES. American Convention of Human Rights. Disponível em: https:// www.cidh.oas.org/basicos/english/basic3.american\%20convention.ht. Acesso em: 4 jan. 2020.

PEREIRA, Lafayette Rodrigues. Princípios de direito internacional. Rio de Janeiro: Jacintho Ribeiro dos Santos, 1903. t. 1.

PEREIRA, Lafayette Rodrigues. Princípios de direito internacional. Rio de Janeiro: Jacintho Ribeiro dos Santos, 1903. t. 2.

ROBINSON, Darryl. The identity crisis of international criminal law. Leiden Journal of International Law, v. 21, n. 4, p. 925-963, 2008.
RORIZ, João. Direitos Humanos como um novo projeto para o direito internacional: notas sobre the Last Utopia, de Samuel Moyn. Brazilian Journal of International Law, v. 15, n. 2, p. 490-496, 2018.

ROY, Arundhati. "Brutality smeared in peanut butter". The Guardian, 2001. Disponível em: https://www.theguardian.com/world/2001/oct/23/afghanistan.terrorism8. Acesso em: 4 jan. 2020.

SCHABAS, William A. Sentencing by international tribunals: a human rights approach. Duke Journal of Comparative \& International Law, v. 7, p. 461-517, 1997.

SCHWARZENBERGER, Georg. From the Laws of War to the Law of Armed Conflict. Current Legal Problems, v. 21, n. 1, p. 239-258, 1968.

SHKLAR, Judith N. Legalism: law, morals, and political trials. Cambridge, MA: Harvard University Press, 1986.

UN HUMAN RIGHTS COMMITTEE. CCPR General Comment No. 29: Article 4: Derogations during a State of Emergency (CCPR/C/21/Rev.1/Add.11). Disponível em: https://www.refworld.org/docid/453883fd1f.html. Acesso em: 4 jan. 2020.

UNITED NATIONS. Convention against torture and Other Cruel, Inhuman or Degrading Treatment or Punishment. Disponível em: https://www.ohchr.org/en/professionalinterest/pages/cat.aspx. Acesso em: 4 jan. 2020.

UNITED NATIONS. International Covenant on Civil and Political Rights. Disponível em: https://www.ohchr.org/ EN/pages/home.aspx. Acesso em: 4 jan. 2020.

UNITED NATIONS SECURITY COUNCIL. Resolution 1373 (S/RES/1373). Disponível em: https://www. unodc.org/pdf/crime/terrorism/res_1373_english. pdf. Acesso em: 4 jan. 2020.

WHIGHAM, Thomas. The paraguayan war: causes and early conduct. 2. ed. Calgary: University of Calgary Press, 2018. 
Para publicar na Revista de Direito Internacional, acesse o endereço eletrônico www.rdi.uniceub.br ou www.brazilianjournal.org.

Observe as normas de publicação, para facilitar e agilizar o trabalho de edição. 